\title{
Effects of siRNA Livin on EJ human bladder cancer cells treated with mitomycin-C
}

\author{
YA-HUI SONG ${ }^{*}$, RAN LIAO* ${ }^{*}$ PENG-CHENG LI, BO GE, LEI-MING JIANG, LI GAO and TIAN-YU ZHANG \\ Department of Urinary Surgery, Affiliated Hospital of Guilin Medical University, Guilin, Guangxi 541001, P.R. China
}

Received October 11, 2014; Accepted June 22, 2015

DOI: $10.3892 / 01.2015 .3527$

\begin{abstract}
The aim of this study was to observe the inhibitory and therapeutic effects of small interfering RNA (siRNA) targeting Livin in EJ human bladder cancer cells. Specific siRNA targeting Livin was synthesized and transfected into EJ human bladder cancer cells treated or not treated with mitomycin-C (MMC). Livin mRNA and protein, as well as proliferation and apoptosis of EJ cells was examined with reverse transcription-polymerase chain reaction, western blotting, Cell Counting Kit-8 assay and flow cytometry, respectively. The results indicated that the expression of Livin mRNA and protein in EJ cells was significantly decreased by siRNA Livin. The proliferation of EJ cells was significantly inhibited by treatment with MMC and transfection of siRNA Livin. The inhibition of cell proliferation by treatment with MMC was further enhanced by transfection of siRNA Livin. The apoptotic rate of cells transfected with siRNA Livin and treated with MMC was significantly higher than those cells receiving a single transfection of siRNA Livin and single treatment of MMC. In conclusion, the present study demonstrates that transfection of siRNA Livin induces growth suppression and apoptosis in EJ human bladder cancer cells, and increases the chemotherapeutic sensitivity of cells to MMC.
\end{abstract}

\section{Introduction}

As a novel member of the inhibitor of apoptosis protein, Livin has been demonstrated to promote cellular proliferation and result in the resistance of tumors to chemotherapeutic medications under overexpression conditions (1). Livin was also revealed to be involved in the apoptosis of human bladder cancer cells through caspase-3 (2) and closely associated with

Correspondence to: Dr Bo Ge, Department of Urinary Surgery, Affiliated Hospital of Guilin Medical University, 15 Lequn Road, Guilin, Guangxi 541001, P.R. China

E-mail: geboguilus@yeah.net

*Contributed equally

Key words: bladder cancer, RNA interference, small interfering RNA, mitomycin-C, chemotherapeutic sensitivity recurrent bladder cancer, indicating the significance of Livin in the treatment of bladder cancer (1,3). Mitomycin-C (MMC) is a widely used antitumor chemical and is suggested to be useful in treating non-invasive bladder tumors (4), while the suppression of Livin may increase the apoptosis of bladder cancer T24 cells induced by MMC (5). This suggests a potential correlation of Livin inhibition with antitumor medications in tumor therapy.

RNA interference (RNAi), including short interfering RNA (siRNA) and short hairpin RNA, is one newly developed technology to silence post-transcriptional genes and is widely used in biopharmaceutical studies (6). Through siRNA and lipofection techniques, the present study delivered specific siRNA targeting Livin into EJ human bladder carcinoma cells to measure the expression of Livin in transfected cells, the effect of siRNA Livin on the apoptosis of EJ cells and the sensitivity of EJ cells to chemotherapeutic medication. This study is expected to provide a further theoretical and experimental basis for the use of chemotherapy in bladder carcinoma.

\section{Materials and methods}

Design of specific siRNA targeting Livin. In accordance with GenBank, the common sequences of isomers ( $\alpha$, NM_139317 and $\beta$, NM_022161) of human Livin (AF311388) designed and synthesized by Shanghai GenPharma Company (Shanghai, China) were sense, 5'-GAGAGAGGUCCAGUCUGAATT-3' and antisense, 5'-UUCAGACUGGACCUCUCUCTT-3'. Non-targeting homologous genes were excluded through comparison with BLAST. Non-human complementary siRNA sequences (sense, 5'-UUCUCCGAACGUGUCACGUTT-3' and antisense, 5'-ACGUGACACGUUCGGAGAATT-3') were used as negative controls and labeled with FAM fluorescence (negative control FAM).

Cell culture and transfection. EJ human bladder carcinoma cells (Nanjing KeyGen BioTech. Co. Ltd., Nanjing, China) were cultured in a $5 \% \mathrm{CO}_{2}$ incubator at $37^{\circ} \mathrm{C}$ with RPMI-1640 medium (HyClone, Logan, UT, USA) supplemented with $10 \%$ fetal bovine serum and $1 \%$ penicillin/streptomycin. EJ cells from the logarithmic phase were inoculated in 6-well or 96-well plates containing RPMI-1640 medium. When the confluence reached $40-60 \%$, the cells were assigned into different groups according to treatment: blank control group (without treatment), intervention group [with the same volume 
of siRNA and Lipofectamine ${ }^{\circledR} 2000$ reagent (Invitrogen Life Technologies, Carlsbad, CA, USA)], chemotherapy group [24 h treatment with $0.1 \mathrm{mg} / \mathrm{ml} \mathrm{MMC} \mathrm{(Sigma-Aldrich,} \mathrm{St.} \mathrm{Louis,} \mathrm{MO,}$ USA)], or combination group (24 h siRNA transfection and $24 \mathrm{~h}$ treatment with $0.1 \mathrm{mg} / \mathrm{ml} \mathrm{MMC)}$. Cells were transfected with negative siRNA or with Lipofectamine 2000 reagent alone. The transfection rate of cells was observed under inverted fluorescence microscopy after 24-48 h (Fig. 1). Our preliminary experiments revealed that the transfection rate in the 6-well plate reached $70 \%$ under conditions of $3 \times 10^{5}$ cells/well, $100 \mathrm{pmol} /$ well siRNA and $5 \mu \mathrm{l} /$ well Lipofectamine 2000 reagent. Similarly, the transfection rate in the 96-well plate reached $70 \%$ under conditions of $4 \times 10^{3}$ cells/well, $5 \mathrm{pmol} /$ well siRNA and $0.25 \mu \mathrm{l} /$ well Lipofectamine 2000 reagent.

Measurement of Livin $m R N A$ with semi-quantitative reverse transcription-polymerase chain reaction (RT-PCR). After $24 \mathrm{~h}$ of transfection, the cells were rinsed with phosphate-buffered saline (PBS) twice, then $1 \mathrm{ml}$ TRIzol was added to the lysate cells. The total RNA was extracted according to the manual and its quantity was measured using a UV spectrophotometer (Beijing ComWin Biotech Co., Ltd., Beijing, China). cDNA was synthesized under conditions of $42^{\circ} \mathrm{C}$ for $40 \mathrm{~min}$ and $85^{\circ} \mathrm{C}$ for $5 \mathrm{~min}$, and used as a template for the amplification of the Livin gene with pre-denaturation at $94^{\circ} \mathrm{C}$ for $2 \mathrm{~min}, 30$ cycles of denaturation at $94^{\circ} \mathrm{C}$ for $30 \mathrm{sec}$, annealing at $60^{\circ} \mathrm{C}$ for $30 \mathrm{sec}$ and extension at $72^{\circ} \mathrm{C}$ for $30 \mathrm{sec}$, then final extension at $72^{\circ} \mathrm{C}$ for $2 \mathrm{~min}$. The sense and antisense primers of Livin and $\beta$-actin genes were 5'-GTGGATGGGCAGATCCTG-3' and 5'-CCTTGTCCTGATGGCCTG-3' (resulting in the production of $214 \mathrm{bp}$ ), and 5'-AGGTGACAGCAGTCGGTTGG-3' and 5'-CGAAGGCTCATCATTCAAAA-3' (resulting in the production of $300 \mathrm{bp}$ ), respectively, synthesized by Beijing AuGCT DNA-SYN Biotechnology Co. Ltd. (Beijing, China). Following the reaction, the PCR production was identified with electrophoresis in $1.5 \%$ sucrose and analyzed with a SensiAnsys gel-imaging system (LI-COR Biosciences, Lincoln, NE, USA). The expression of Livin mRNA was semi-quantitatively calculated using the optical density ratio of Livin and $\beta$-actin. The experiment was repeated three times.

Measurement of Livin protein with western blot analysis. Following $48 \mathrm{~h}$ of transfection, the EJ cells were removed from the medium, rinsed twice with pre-cooled PBS, mixed with $100 \mu 1$ RIPA lysis buffer and $10 \mu \mathrm{l}$ PMSF in an ice-bath for $10 \mathrm{~min}$, and centrifuged at $12,000 \mathrm{rpm}$ at $4^{\circ} \mathrm{C}$ for $10 \mathrm{~min}$. The total cellular protein was collected and quantified with the bicinchoninic acid assay. Then $30 \mu \mathrm{g}$ protein was loaded onto $12 \%$ polyacrylamide gel for electrophoresis to isolate the protein, which was transferred to a polyvinylidene fluoride membrane using the semi-dry method and blocked with Tris-buffered saline and Tween-20 (TBST) solution containing $5 \%$ skimmed milk at room temperature for $2 \mathrm{~h}$. Primary Livin antibody (1:500) and $\beta$-actin antibody (1:1000; both from Beijing ComWin Biotech Co., Ltd.) were added for incubation at $4^{\circ} \mathrm{C}$ overnight. The membrane was rinsed with TBST three times and horseradish peroxidase-conjugated secondary antibodies (goat anti-rabbit 1:2000; Beijing ComWin Biotech Co., Ltd.) were added for incubation at room temperature for $1 \mathrm{~h}$. After washing, the membrane was developed with the enhanced chemiluminescence method and exposed under a photographic system. The optical density of Livin protein was compared with that of $\beta$-actin as an internal reference. The experiment was repeated three times.

Cellular proliferation measurement by Cell Counting Kit-8 (CCK-8) assay. The cells were inoculated in 96-well plates at $100 \mu \mathrm{l} /$ well with five repetition wells for each group, and cultured in a $5 \% \mathrm{CO}_{2}$ incubator at $37^{\circ} \mathrm{C}$. Then the medium was replaced by $10 \mu \mathrm{l} \mathrm{CCK-8} \mathrm{(Shanghai} \mathrm{Yeasen} \mathrm{Biotech} \mathrm{Company,}$ Shanghai, China) for $2 \mathrm{~h}$ incubation and the absorption (D) was measured at $450 \mathrm{~nm}$ to calculate the relative inhibition rate of cell proliferation according to the formula: inhibition rate $(\%)=$ [(D in control group - D in experimental groups) / D in control group] $\mathrm{x} 100 \%$. The experiment was repeated three times.

Measurement of cell apoptosis by flow cytometry. EJ cells were inoculated in six-well plates as above. Following treatment, the cells were digested with ethylenediaminetetraacetic acid-free trypsin and centrifuged at 2,000 rpm at room temperature for $5 \mathrm{~min}$. Then the cells were re-suspended with $1 \mathrm{X}$ PBS $\left(4^{\circ} \mathrm{C}\right)$ and centrifuged. After removal of the supernatant, the cells were mixed with $300 \mu 11 \mathrm{X}$ binding buffer and $5 \mu \mathrm{l}$ Annexin V-FITC (Beijing Jiamay Biotech, Beijing, China), gently agitated and incubated at room temperature in the dark for $45 \mathrm{~min}$. Then the cell suspension was filtered with a 300-mesh nylon net into the flow tube. A total of $5 \mu \mathrm{l}$ propidium iodide and $200 \mu \mathrm{l} 1 \mathrm{X}$ binding buffer was added 5 min prior to and immediately before loading. The apoptosis was measured by BD FACSAria-III (Beijing Jiamay Biotech) and analyzed with Modfit LT3.3 (Verity Software House, Topsham, ME, USA). The experiment was repeated three times.

Statistic analysis. All data were expressed as the means \pm standard deviation. SPSS 19.0 (IBM SPSS, Armonk, NY, USA) was used for analysis with one-way analysis of variance. $\mathrm{P}<0.05$ was considered to indicate a statistically significant difference.

\section{Results}

Inhibition of Livin mRNA by siRNA. After $24 \mathrm{~h}$ of transfection with siRNA Livin, the expression intensity of Livin mRNA in the blank control, negative control, liposome and intervention group (siRNA Livin) was $0.271 \pm 0.032,0.301 \pm 0.043,0.292 \pm 0.036$ and $0.024 \pm 0.011$, respectively, indicating that siRNA Livin significantly inhibited the expression of Livin mRNA $(\mathrm{P}<0.01)$. There was no significant difference between the blank control, negative control and liposome group ( $\mathrm{P}>0.05$, Fig. 2A).

Inhibition of Livin protein by siRNA Livin. Western blot analysis further indicated that the Livin protein in EJ cells was significantly decreased following the decrease of gene transcription. After $48 \mathrm{~h}$ of transfection, the relative expression of Livin protein in the blank control, negative control, liposome and intervention group (siRNA Livin) was $0.515 \pm 0.038$, $0.539 \pm 0.047,0.521 \pm 0.043$ and $0.070 \pm 0.016$, respectively. The statistic analysis indicated that Livin protein in EJ cells was significantly decreased following transfection of siRNA Livin $(\mathrm{P}<0.01)$. There was no significant difference between the blank control, negative control and liposome group ( $\mathrm{P}>0.05$, Fig. $2 \mathrm{~B})$. 
Table I. Inhibition of proliferation of EJ cells in different groups (mean \pm standard deviation).

\begin{tabular}{lcr}
\hline Groups & Optical density & Inhibition rate $(\%)$ \\
\hline Blank control group & $0.862 \pm 0.174$ & $2.14 \pm 0.761$ \\
Intervention group & $0.794 \pm 0.163$ & $7.787 \pm 4.032^{\mathrm{a}, \mathrm{b}}$ \\
Chemotherapy group & $0.660 \pm 0.156$ & $23.375 \pm 7.813^{\mathrm{a}, \mathrm{b}}$ \\
Combination group & $0.471 \pm 0.096$ & $45.355 \pm 5.617^{\mathrm{b}}$
\end{tabular}

${ }^{\mathrm{a}} \mathrm{P}<0.01$ vs. combination group, ${ }^{\mathrm{b}} \mathrm{P}<0.01$ vs. blank control group; $\mathrm{n}=15$ for each group.
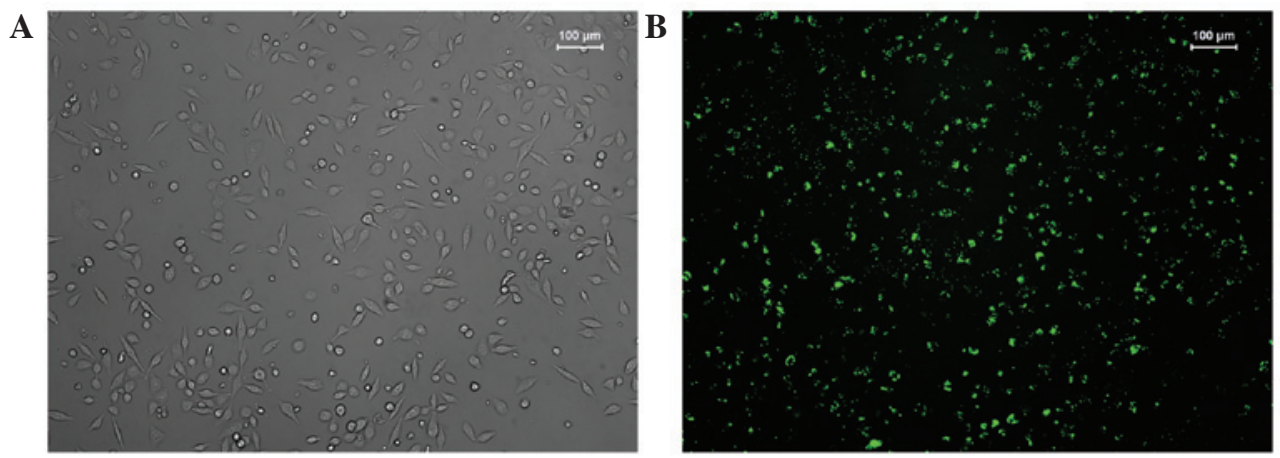

Figure 1. EJ bladder carcinoma cells in blank control group (A) and transfected with negative siRNA Livin (B) under inverted fluorescence microscopy (magnification, $\mathrm{x} 400$ ).

A
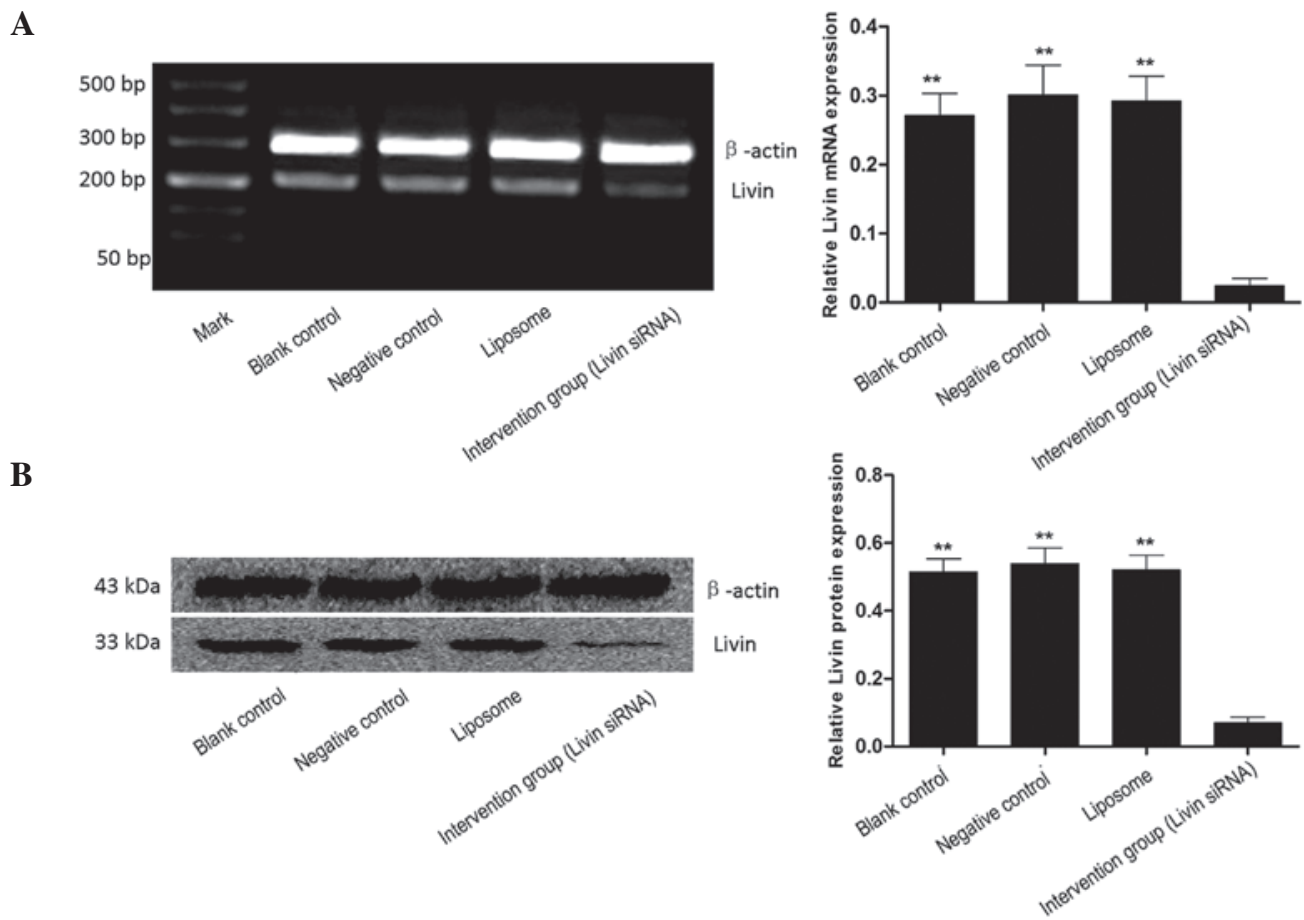

Figure 2. Expression of Livin mRNA (A) and protein (B) in different groups after 24 and $48 \mathrm{~h}$ transfection with siRNA Livin. ${ }^{* *} \mathrm{P}<0.01$ represents the relative Livin mRNA expression in blank control, negative control or lipofectamine groups compared with siRNA-treated cells.

Inhibition of EJ cell proliferation by siRNA Livin. Measurement of CCK-8 indicated that the proliferation of EJ cells was inhibited by siRNA Livin. The inhibition in the combination group was significantly higher than in the single intervention and single chemotherapy group $(\mathrm{P}<0.01$, Table I).
Promotion of apoptosis of EJ cells by siRNA Livin. The flow cytometry assessment indicated that apoptosis was promoted in the intervention group $(15.29 \pm 1.64 \%)$, chemotherapy group $(17.57 \pm 0.82 \%)$ and combination group $(40.19 \pm 1.53 \%)$, when compared with the blank control group $(1.18 \pm 0.47 \%$; $\mathrm{P}<0.01)$. 

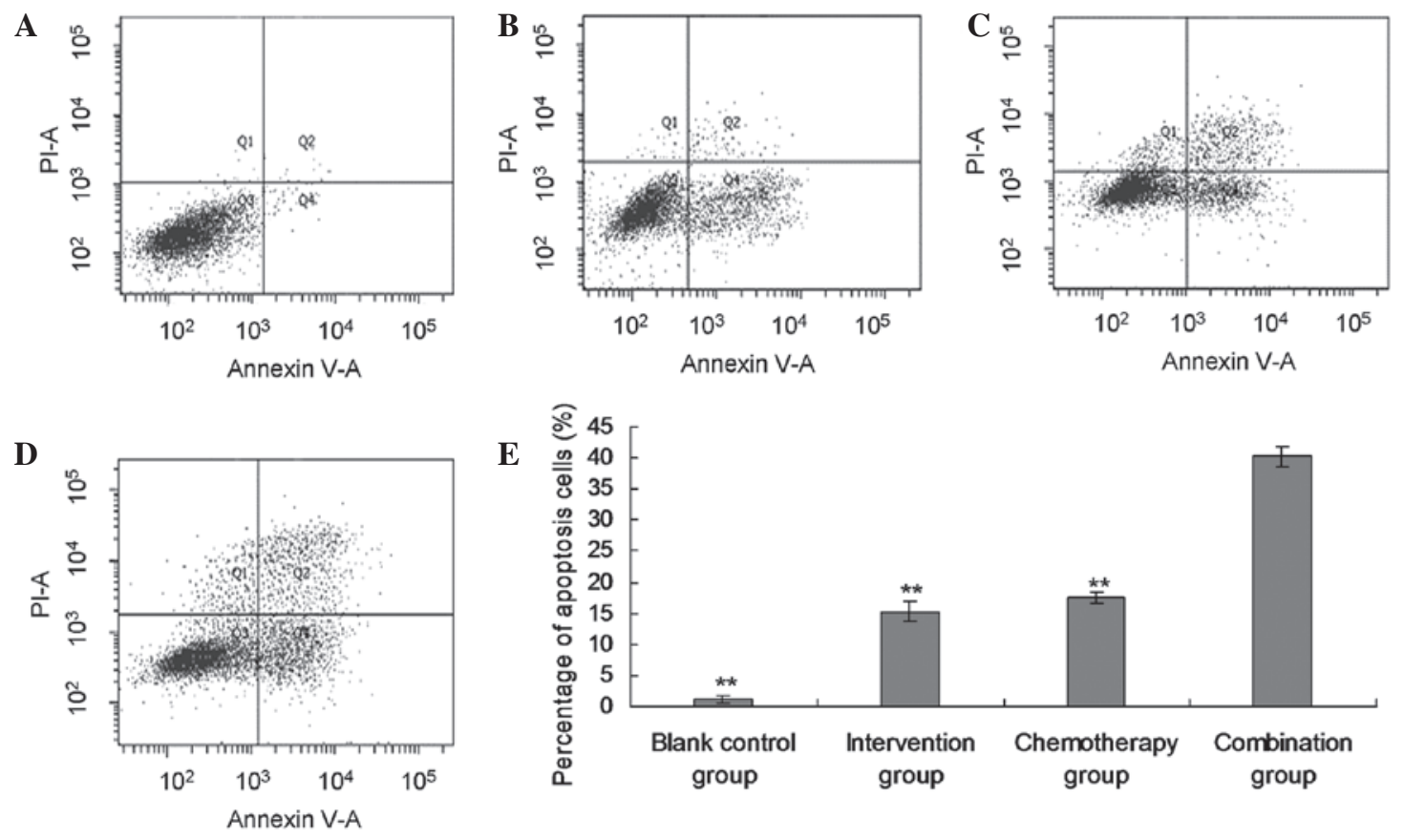

Figure 3. Apoptosis of EJ cells in (A) blank control group, (B) intervention group (C) chemotherapy group and (D) combination group. (E) The difference among the four groups was also statistically analyzed. ${ }^{* * *} \mathrm{P}<0.01$ represents the apoptotic cell percentage in the blank control, intervention and chemotherapy groups compared with the combination group.

Furthermore, the apoptotic rate in the combination group was significantly higher than in the single intervention and single chemotherapy group $(\mathrm{P}<0.01$, Fig. 3).

\section{Discussion}

Bladder carcinoma is the most common malignant tumor of the urinary system and one of the 10 most common tumors of the whole body. Although there are multiple strategies of accessory intra-bladder perfusion with variable medications following surgery, the recurrence rate is still high, which is mainly due to the resistance of tumor cells to chemotherapeutic medication (7). Therefore, finding new targeting sites and enhancing chemotherapeutic sensitivity are critical for the therapy of bladder carcinoma. Previous studies indicated that Livin is not expressed or expressed at low levels in most differentiated terminal tissues of adults, but overexpressed in a number of malignant tumors (8-10). Overexpression of Livin inhibits the apoptosis of tumor cells and leads to the resistance of tumors to pro-apoptotic factors $(11,12)$. In addition, Livin is associated with the invasiveness of tumors and oncogenic phenotypes (13). These studies suggest that Livin is one potential targeting site for the therapy of bladder carcinoma.

siRNA is a small segment of RNA with specific length and structure ( 21-23 bp). It binds to certain enzymes to form RNA-induced silencing complex which specifically binds to and cuts the homologous regions of mRNA expressed by exogenous genes, resulting in the degradation of specific mRNA $(14,15)$. siRNA has previously been used in biological experiments which have led to the development of new pathways of tumor therapy, due to siRNA's features of strong specificity, high efficiency and simple operation $(2,16)$. The present study indicated that siRNA Livin inhibited the proliferation and enhanced the apoptosis of EJ human bladder carcinoma cells, suggesting the effectiveness and practicality of siRNA Livin in treating bladder carcinoma.

Furthermore, CCK-8 measurement and flow cytometry revealed that growth inhibition and apoptosis of EJ cells was greatest in the combination group, followed by the chemotherapy group, then the intervention group. These results suggest that transfection of EJ cells with siRNA Livin enhances the sensitivity of EJ cells to chemotherapeutic medications, which is consistent with a previous study using T24 human bladder cancer cells (5). The mechanism has been suggested to involve caspase-3 (2).

In summary of the present study, effective siRNA Livin was designed, which inhibited the expression and proliferation of Livin in EJ human bladder carcinoma cells, and promoted apoptosis. siRNA Livin also enhanced the sensitivity of EJ cells to MMC. These results provide a theoretical basis and experimental evidence to support therapy of bladder carcinoma using siRNA Livin.

\section{Acknowledgements}

This study was supported by grants from the Scientific Research Fund of Guangxi Provincial Education Department (grant no.'s 200911LX290, 200103YB092) and the Scientific Research and Technology Development Projects of Guilin City (grant no. 20100315-3).

\section{References}

1. Chen X, Wang T, Yang D, Wang J, Li X, He Z, Chen F, Che X and Song X: Expression of the IAP protein family acts cooperatively to predict prognosis in human bladder cancer patients. Oncol Lett 5: 1278-1284, 2013. 
2. Liu C, Wu X, Luo C, Hu Z, Yin Z, He Y, Du H, Zhang W, Jiang Q and Lin Y: Antisense oligonucleotide targeting Livin induces apoptosis of human bladder cancer cell via a mechanism involving caspase 3. J Exp Clin Cancer Res 29: 63, 2010.

3. Xi RC, Sheng YR, Chen WH, Sheng L, Gang JJ, Tong Z, Shan Z, Ying GH and Dong LC: Expression of survivin and livin predicts early recurrence in non-muscle invasive bladder cancer. J Surg Oncol 107: 550-554, 2013

4. Wang D, Jiang Y, Ouyang S, Liu B, Zhu T, Niu H and Tian Y: Inhibitory effect of valproic acid on bladder cancer in combination with chemotherapeutic agents in vitro and in vivo. Oncol Lett 6: 1492-1498, 2013

5. Yang D, Song X, Zhang J, Ye L, Wang S, Che X, Wang J, Zhang Z and Wang L: Suppression of livin gene expression by siRNA leads to growth inhibition and apoptosis induction in human bladder cancer T24 cells. Biosci Biotechnol Biochem 74: 1039-1044, 2010.

6. Kubowicz P, Żelaszczyk D and Pekala E: RNAi in clinical studies. Curr Med Chem 20: 1801-1816, 2013

7. Kang XL, Geng ZH, Lu XX, Wei C, Wang JG, Wang SZ, Ma S, Liu HX, Xu GY, Zhang HW and Wang GY: Detecting multi-drug resistance of bladder cancer for the intravesical chemotherapy. Zhonghua Wai Ke Za Zhi 42: 285-287, 2004.

8. Guo H, Gao YT, Zhang Q, Jing L, Liu T, Shi WX, Zhai DK, Jing X and Du Z: Expression and clinical significance of livin protein in hepatocellular carcinoma. Dis Markers 35: 489-496, 2013.

9. Chung CY, Park YL, Kim N, Park HC, Park HB, Myung DS, Kim JS, Cho SB, Lee WS and Joo YE: Expression and prognostic significance of Livin in gastric cancer. Oncol Rep 30: 2520-2528, 2013.
10. Xu M, Xia LP, Fan LJ, Xue JL, Shao WW and Xu D: Livin and caspase-3 expression are negatively correlated in cervical squamous cell cancer. Eur J Gynaecol Oncol 34: 152-155, 2013.

11. Ding ZY, Liu GH, Olsson B and Sun XF: Upregulation of the antiapoptotic factor Livin contributes to cisplatin resistance in colon cancer cells. Tumour Biol 34: 683-693, 2013.

12. Sun JG, Liao RX, Zhang SX, Duan YZ, Zhuo WL, Wang XX, Wang ZX, Li DZ and Chen ZT: Role of inhibitor of apoptosis protein Livin in radiation resistance in nonsmall cell lung cancer. Cancer Biother Radiopharm 26: 585-592, 2011.

13. Chung CY, Park YL, Kim N, Park HC, Park HB, Myung DS, Kim JS, Cho SB, Lee WS and Joo YE: Expression and prognostic significance of Livin in gastric cancer. Oncol Rep 30: 2520-2528, 2013.

14. Hannon GJ: RNA interference. Nature 418: 244-251, 2002.

15. Zhou W, Chen H, Hong X, Niu X and Lu Q: Knockdown of DNA methyltransferase-1 inhibits proliferation and derepresses tumor suppressor genes in myeloma cells. Oncol Lett 8: 2130-2134, 2014.

16. Płuciennik E, Nowakowska M, Stępien A, Wołkowicz M, Stawiński A, Różański W, Lipiński M and Bednarek AK: Alterating expression levels of WWOX tumor suppressor and cancer-related genes in patients with bladder cancer. Oncol Lett 8: 2291-2297, 2014 